\title{
Landlord Paternalism: Housing the Poor with a Velvet Glove
}

\author{
Eva Rosen, Georgetown University ${ }^{1}$ \\ Philip ME Garboden, University of Hawai i at Mānoa \\ Forthcoming in Social Problems
}

\footnotetext{
${ }^{1}$ Contact Eva Rosen, eva.rosen@georgetown.edu for all correspondence. The authors would like to thank Jennifer Darrah, Stefanie DeLuca, Kathryn Edin, Meredith Greif, Barbara Kiviat, Ann Owens, Noah Saganski, Stephen Wong. Funding for this research was provided by the Department for Housing and Urban Development, the Furman Center for Real Estate and Urban Policy, and the MacArthur Foundation.

Disclaimer: The work that provided the basis for this publication was supported by funding under a grant with the U.S. Department of Housing and Urban Development. The substance and findings of the work are dedicated to the public. The author and publisher are solely responsible for the accuracy of the statements and interpretations contained in this publication. Such interpretations do not necessarily reflect the views of the Government.
} 


\title{
Landlord Paternalism: Housing the Poor with a Velvet Glove
}

\begin{abstract}
:
As a key actor in housing the poor, the private landlord plays an important role in America's poverty governance, with profound effects on poor families and their neighborhoods. Drawing on data from in-depth interviews with 127 landlords in Baltimore, Dallas, and Cleveland, we ask how landlords think about their role as purveyors of affordable housing. We find that landlords think about their tenants in moral terms, drawing upon cultural categories to describe and define their tenants. Landlords see renting to the urban poor as a social good insofar as it facilitates a civilizing mission that houses those in need on the condition of their moral reform. We identify two components of this strategy: exclusion and reform. On the one hand, landlords pursue profit through exclusionary tactics such as screening and eviction. While recent research has focused on this component, this article explores how landlords also invest resources in "training" tenants, attempting to mold them into a profitable ideal, rather than replacing them. Using both incentives and surveillance, landlords seek to create a tenant class that conforms to mainstream notions of responsibility and self-reliance. We argue that exclusion and reform are two sides of the same coin, that is, complementary components of paternalistic poverty governance. Landlord paternalism carries special salience in today's increasingly privatized federal housing policy, where landlords have a great deal of discretion and little oversight.
\end{abstract}

"Once a house is built and tenants move in, an organism has been created whose development thereafter depends mainly upon good management... The effectiveness [of a manager] will depend upon his ingenuity, his resourcefulness, and his understanding of people."

- (Goldfeld 1940:vii)

\section{Introduction}

Housing America's poor has always been a dual endeavor: a profit-seeking enterprise, tinged with a moral mission (Goetz 2013; Stuart 2016; Vale 2000). A large literature documents how poverty governance — at the intersection of welfare reform and the carceral state — serves a paternalistic function in the lives of the poor, promoting civic incorporation, social control, and the production of self-regulating subjects (Katz 1997; Mead 1997; Piven and Cloward 1993; Soss, Fording, and Schram 2011; Wacquant 2009). The role of housing policy, however, has been largely overlooked. When researchers have considered the intersection of housing and poverty governance, they have tended to focus on the now atypical cases of families living in public housing (Popkin 2016; Popkin et al. 2000), the homeless (Main 1997; Stuart 2016), or 
residents of mixed income communities (Chaskin and Joseph 2015; Tach 2009). While compelling, none of these contexts represent the modal form of American housing policy: poor families living in privately owned and managed housing, subsidized through vouchers or tax credits (Schwartz 2015). This reliance on the private market to house the poor means that landlords serve as front-line implementers of contemporary social policy, playing a central role in how the poor access, experience, and live in their homes. Yet we know little about how landlords think about and enact their role as the purveyors of affordable housing, and what consequences this may have for tenants.

At its core, paternalistic poverty governance entails the expansion of the welfare state beyond the provision of goods and services, and into a broad program of behavioral reform (Katz 1997; Mead 1997; Piven and Cloward 1993; Soss et al. 2011; Wacquant 2009). While paternalism's proponents tend to focus on its role in allowing the poor to participate more fully in America's social and political spheres, contemporary poverty governance involves economic incorporation as well; to be a full and productive citizen is to be a participant in the market as both worker and consumer (Soss et al. 2011). It is thus inexorably linked to the neoliberal trend of leveraging private markets to solve social problems.

This trend is nowhere more visible than in housing. The rapid rise and fall of public housing initiated a decades-long retreat from the direct provision of housing aid to a diffuse system of private actors (Hackworth 2007). While the trend towards contracting is a common feature of contemporary governance (Osborne and Gaebler 1993; Soss et al. 2011), the case of housing is striking in the degree of autonomy given to the private entities responsible for implementation. Rental property owners who house families through the Housing Choice Voucher (HCV) Program are required to maintain their properties to reasonable standards but are 
otherwise granted discretion in terms of tenant screening, property management, and so forth. Unlike the welfare agencies described by Soss et al. (2011) or the homeless service agencies described by Stuart (2016), the Department of Housing and Urban Development (HUD) does not incentivize landlords to promote client self-sufficiency nor require them to police tenants' behavior.

The particular nature of housing policy leaves open to empirical inquiry the question of how landlords operate within the field of poverty governance. To what degree do they embrace the paternalistic ideologies that are nearly hegemonic in the American welfare system? How do they interpret their tenants' lives and their own role within them? And finally, how do these beliefs translate into specific tenant management practices?

We use data from 127 interviews and observations with landlords and property managers in Baltimore, Maryland, Dallas, Texas, and Cleveland, Ohio, the majority of whom were randomly sampled from listings actively seeking tenants with housing vouchers. We find that landlords — like other state actors (Steensland 2006) — draw on moral categories to think about their tenants, which in turn inform their approaches to tenant management. In a context in which the vast majority of household heads are black and female, landlords draw on common narratives of the "culture of poverty" —or the idea that the poor are responsible for their own conditionalong three axes of American stratification: race, class, and gender. Rather than simply compounding upon each other, these three axes represent a point of intersectionality for poor black women that drives the way landlords think about their tenants (see Collins 1990, 2015; Crenshaw 1989; Lutz, Herrera, and Supik 2011). They speak of their tenants as incomplete citizens who require an education in the mores and values of mainstream American culture, as 
mothers unfit to instill moral values in their children, and as subjects vulnerable to predatory male influences.

Landlords take a paternalist approach to management, exemplified by the two explicit modes: reform and exclusion. The latter-pursuing profit through exploitation and purging tenants who do not pay-is well highlighted in recent literature (Desmond 2016; Garboden and Rosen 2019; Hartman and Robinson 2003; Purser 2014). We likewise find a portion of landlords who manage predominantly by purging undesirable tenants through eviction. These landlords perceive their tenants to be unworthy and refuse to work with them. In these cases, landlords employ moral categories that place some tenants beyond help or not deserving of reform. The results are — as Desmond has shown — summarily disruptive and thus dis-incorporating (2016).

But we also see significant evidence of another component of paternalism: reform. Because the intersectional identity of poor, black, and female tenants allows landlords to access stereotypes of vulnerability and moral incompetence, many of our respondents implement management strategies that attempt to mold renters into responsible (and thus profitable) citizens. As described in detail below, landlords draw on racist folk theories of ghetto poverty and believe that their tenants do not value their homes (cf. Banfield 1970). Thus, these landlords attempt to "teach" tenants the moral value of caring for their homes, including specific instructions on how and when to cut the grass, unclog drains, and maintain appliances. Similarly, landlords often see their female tenants as victims preyed upon by male partners and intervene by offering unsolicited relationship advice and enforcing strict rules to keep non-lease-holding men out of the home.

This reformist mode of tenant management defies easy stereotypes, engendering a deeply personal model of power and profit. Using a carefully crafted combination of carrots and sticks - 
incentives on the one hand, and tactics of surveillance and control on the other - landlords cultivate behavior to shape tenants into "good" consumers of rental housing who conform to mainstream notions of fiscal responsibility, accountability, and self-reliance.

Together, the two-pronged strategy of exclusion and reform carries special salience in today's increasingly privatized subsidized housing programs, where landlords have ever more discretion in how to select, manage, and exclude tenants. We argue that reform and exclusion are two complementary components of paternalist poverty governance. In this paper we ask whether landlords, even as fairly autonomous private actors, embrace and reenact the same moral demands on tenants as exist in other anti-poverty programs.

\section{Landlording as Poverty Governance}

The owners and managers of rental properties have figured in narratives of urban poverty since the earliest days of the industrial city, from Engels' and Riis' overcrowded slums (1845; 1890), to Smith's displacement narratives (1996), to Desmond's depictions of housing insecurity and eviction (2016). But outside of a few broad statistical accounts nearly half a century old (Stegman 1972; Sternlieb 1966, 1972) and retrospective works of urban history (Blackmar 1991; Connolly 2014; Satter 2009), how landlords think about and interact with tenants remains a gap in the literature. Landlord behavior affects the lives of poor families in profound ways, including housing quality (Dedman et al. 2001; Evans 2003), crowding (Solari and Mare 2012), lead-paint exposure (Markowitz and Rosner 2013), affordability (Quigley and Raphael 2004), residential stability (Gasper, DeLuca, and Estacion 2010; Hanushek, Kain, and Rivkin 2004), racial segregation (Massey and Denton 1993), discrimination (Turner et al. 2002; Yinger 1997), concentrated disadvantage (Sampson 2012; Wilson 1987) and eviction (Desmond 2012, 2016; Hartman and Robinson 2003; Purser 2014). 
Landlords serve as the middle-men of social stratification, acting as filters between the whims of the market, the nature of supply, and the ebbs and flows of demand, reflecting and recreating existing patterns of residential inequality. Our inquiry into landlord management strategies and attitudes toward their tenants is set within a context of the outsourcing of subsidized housing to the private market and the greater role of landlords in housing the poor. The last four decades have shown a steady increase in subsidized housing owned and managed by for-profit actors (Hackworth 2007; Schwartz 2015; Spence 2015). This trend began with Nixon's 1974 moratorium on public housing construction, continued through large-scale demolition via HOPE VI, and is currently being enacted through the Rental Assistance Demonstration (RAD) (Galster 2008; Goetz 2003, 2011; HUD 2014b; Landis and McClure 2010). This broad federal commitment to market-based solutions has resulted in the subsidization of 2.4 million housing voucher units, 1.2 million privately-owned Project Based Section 8 units, and 2.2 million units funded with Low-Income Housing Tax Credit (LIHTC) subsidies, compared to just over 1 million remaining public housing units (HUD 2014a, 2016; Schwartz 2015).

The U.S. social safety net has a long history of efforts to "regulate," "punish," “discipline," and "improve" the poor (Katz 1997; Lipsky 1980; Piven and Cloward 1993; Soss et al. 2011; Wacquant 2009). This regulation has historically served three objectives: civic incorporation, social control, and the production of self-regulating subjects (Soss et al. 2011). Poverty governance consists of the protective, welfare arm of the state on the one hand, (Watkins-Hayes 2009), and the punitive, carceral arm on the other (Simon 1997; Stuart 2016; Wacquant 2009; Western 2007). Poverty governance in the U.S. today—what some call the "new paternalism" - consists of training, incentives, and nudges, as well as a disciplinary 
approach including mandates, surveillance, and sanctions (Schram et al. 2009). Thus, the state manages the poor by mandating their rise to citizenship requirements as a condition of support, with punitive sanctions otherwise (Mead 1997).

The degree to which there is anything "new" about the "new paternalism" is debated (see Jackman 1994; Mead 1997; Soss et al. 2011; Stuart 2016). While there has undeniably been a transition in American domestic policy since the New Deal (Mead 1997; Soss et al. 2011), there is nothing novel about attempts to reform poor people—particularly poor minorities—as a condition of receiving aid and the equal rights of citizenship (Muhammad 2011). Such logics not only motivated much of progressive era aid (Patterson 1981; Vale 2000), but also provided the backbone for the colonialist system of exploitation (Moore 2017). Mary Jackman's canonical The Velvet Glove argues that researchers have perennially overestimated the importance of open conflict and underestimated the less visible use of paternalism within exploitative social relations (1994). For Jackman, the dominant groups of society "resort to alternative modes of persuasion [such as violence]" (1994:9) only out of desperation, preferring instead more "subtle and insidious" processes of subordination (1994:2).

What is certainly new, however, is the degree to which this paternalistic approach to governance converges with the parallel movement of neoliberalism. While in the 1970s and 80s neoliberalism operated through laissez-faire policies that weakened state regulations, it has now shifted to harness - and even expand — the power of the state by organizing its functions around principles of market rationality (Hackworth 2007; Osborne and Gaebler 1993; Spence 2015). Paternalism and neoliberalism join to form the "hollow state," where government functions are outsourced to the private sector (Milward and Provan 2000) in a unique moment of strong state enforcement operating through a diffuse network of quasi-market actors to regulate the poor 
(Soss et al. 2011). This transference to the private sector is significant because private actorslandlords - now perform the regulatory functions previously enacted by the government, while employing market logics.

Decentralization has increased the administrative burden placed on local and state actors to implement federal safety net programs, which local agencies have in turn passed to profitseeking actors (Herd et al. 2013). Private landlords have become the latter-day version of Lipsky's "street-level bureaucrats"; as they exercise discretion, establish routines, and create protocols, they significantly shape social service provision (1980). We understand landlords as an extension of the hollow state, playing a key role in regulating the poor through the housing market. We argue that landlording follows this dual function in neoliberal poverty governance: On the one hand encouraging the poor to become compliant, self-governing citizens, and on the other hand controlling, disciplining, punishing, and excluding the poor when they fail to meet these criteria. Recent research highlights the retributive side of landlording, showing how eviction acts as a punitive marker for poor women (Desmond 2012), much like a criminal record for men (Pager 2003; Western 2007). Bringing it into alignment with the poverty governance literature, eviction can be thought of as the "failsafe," used when "incentives and rules prove insufficient" (Schram et al. 2009:399), but little information exists on how those incentives and rules operate within housing.

Poverty governance is heavily shaped by moral evaluations of the poor. These moral evaluations are used to draw symbolic boundaries, or "conceptual distinctions between objects, people and practices" that "distinguish between those who are worthy and those who are less so, from the standpoint of morality, economic success, cultural sophistication" (Lamont and Small 2008:84-85). These boundaries operate as a "system of rules that guide interaction by affecting 
who comes together to engage in what social act" (Lamont and Fournier 1992, 12), and they are instantiated in the social world in key processes such as residential segregation and labor market segregation that reinforce inequality (Lamont and Molnar 2002). Moral evaluations reveal distinctions made by individuals and groups about those from other social backgrounds. For example, Lamont finds that working-class American's "self-definitions stress hard work, responsibility, and self-sufficiency. In valuing their own attributes, they draw strong moral boundaries against the poor, whom they view as lazy and taking advantage" (Lamont 2000). The power of intersectional cultural categories of worth shapes policy toward the poor in important ways (Steensland 2006). Central to our question is how moral evaluations wielded by private actors - landlords - shape their implementation of government programs.

Given this review, it remains an open question how much landlords enact the paternalism found in other forms of poverty governance. The focus of much recent literature on eviction, combined with historical accounts of slumlords, serve to highlight the exclusionary aspects of landlord-tenant relations. It is entirely plausible that exclusion, emerging sporadically from a baseline of neglect, represents a totalizing management practice among urban landlords with low-end and subsidized properties. But to suggest as much would be to ignore the two-sided nature of paternalistic governance, which merges the constant threat of exclusion with a broad program of behavioral reform. As an empirical question, we ask how these historical shifts matter for how landlords enact the growing participation in poverty governance. How do landlords think about and enact their role as the purveyors of affordable housing, and what consequences does this have for tenants?

\section{DATA AND METHODS}


Our three research sites represent a range of urban contexts. Baltimore and Cleveland share a paradigmatic rustbelt history, with explosive population and industrial growth prior to World War II and the well-documented decline thereafter (Citizens Planning And Housing Association of Baltimore (CPHA) 1941; Green 1930; Joint Committee on Negro Housing 1951; Kusmer 1976; Orser 1997). Dallas represents a newer urban form, reflecting the steady expansion of America's sun belt (Gibson 1998). Perhaps surprisingly, given its reputation as a new economic powerhouse, Dallas city's poverty rate is nearly identical to that of Baltimore city (24.1 and 24.2 percent respectively) (ACS 2014). Cleveland, in contrast, is the poorest city in our sample, with a poverty rate of 35.9 percent (ACS 2014). The housing stock in Baltimore and Cleveland are substantially older; less than 20 percent of houses were built after 1960 compared to nearly two thirds of houses in Dallas (ACS 2014). Dallas' rental housing is dominated by large, professionally owned and managed apartment complexes. In contrast, both Baltimore and Cleveland are more fragmented, with many small and amateur owners (Garboden et al. 2018). This paper uses data from 127 in-depth interviews and ethnographic observations with landlords and property managers in Baltimore, Cleveland, and Dallas. Interviews were drawn from a stratified random sample of geocoded rental property listings collected over three months from the most common online listing services (gosection8.com, craigslist.com, and housingcleveland.org). We stratified based on active marketing to subsidized tenants, tract poverty rate (above/below 20 percent), and racial composition (black/white in Cleveland and Baltimore, black/white/Hispanic in Dallas). For the sample drawn from Craigslist, we removed any properties that were listed above 150 percent of HUD's Fair Market Rent (FMR), in order to target the affordable housing market. We sampled on one focal property, but most landlords had more diverse portfolios with a range of properties, including some rented to higher income 
tenants. We supplemented this random sample with a targeted "field" sample, designed to allow us to add in landlords, investors, and managers who we learned about during the course of fieldwork who were interesting or important in the local housing market. This resulted in 127 interviews with landlords, 80 from the random sample and 47 from the field sample. As detailed in Table 1, 40 percent of the landlords sampled are black, 47 are white; 60 are male. About three quarters own rental properties, a third manage other people's properties, and some do both. Reflecting the distribution of urban rental real estate (Fields 2015; Ioannides and Rosenthal 1994; Mallach 2006; Raymond et al. 2016; Shroder 2001), over 60 percent own or manage fewer than 30 units, while 22 own or manage more than 100. The differences between the three sites followed the expected patterns described above.

\section{[TABLE 1 ABOUT HERE]}

Each interview lasted approximately two hours and focused on landlords' business strategies and professional and personal histories. A subset of interviews were accompanied by ethnographic observations with the landlord as he or she attended to day-to-day business. We also examined the field of landlording more broadly in each city, spending days in housing court, riding along with sheriff's deputies as they conducted evictions, speaking with city officials and tenant advocates, attending real estate auctions, and joining investor association meetings.

Given that real estate is a fairly diverse field in terms of age, gender, and race, systematic demographic differences between the interview team and our respondents did not greatly impact the observations. The majority of interviews were conducted by the authors, both of whom are white (one is male, the other female). This may have enabled more candid responses from our non-black respondents regarding their black tenants particularly when overlaid with respondents' assumptions of a shared class position. Our interview process, however, relies not on 
commonalities and perceived solidarities, but on situating the researcher in the position of a learner and the respondent in the position of the teacher. Many landlords believe that public perception is normatively biased against them and were interested in correcting such perception to a receptive audience.

During the interview process, we build rapport both by listening, as well as observing, letting landlords share their experiences and frustrations openly. These stories can provide valuable information about a landlord's day to day experiences, especially when the interviewer probes for the interviewee to contextualize an "extreme" story with a "typical" one. We started by asking open-ended questions that enabled our respondents to tell us detailed stories that encompassed details relevant to many of our topics of inquiry at once (see also (Garboden and Rosen 2018). When a respondent tells a story, they open a window into an entire experience related to a particular issue and are therefore less likely to massage specific details in response to the wording of a question (problems that psychologists call priming, or social desirability bias). We also incorporate participant observation into the data collection process. This serves to both build rapport, as well minimize the attitudinal fallacy (Jerolmack and Khan 2014).

All interviews were recorded, transcribed verbatim, matched to ethnographic fieldnotes, and loaded into qualitative data analysis software (MaxQDA). Respondents were assigned pseudonyms and other identifying information was changed. For data analysis, we employed a process of iterative inductive coding related to our research question (Corbin and Strauss 1990).

\section{FINDINGS}

\section{Symbolic Boundaries and the Ideology of Responsibility}

Landlords' moral evaluations of tenants play a variety of roles: from how they define what makes a good tenant, to finding that tenant, to interacting with the tenants once they move 
in, to interpreting tenant behavior, and to deciding who is responsible for maintenance problems. Our interviews show that landlords interpret many straightforward issues—an un-mowed lawn, a broken sink, a late rent payment—in moral terms, integrating them into a normative classification schema defined by cleanliness, politeness, planning, responsibility, resourcefulness, and frugality.

According to landlords, there are three basic qualities that make a good tenant: 1) paying the rent; 2) communicating with the landlord; and 3) contributing to routine maintenance of the property. In the words of Keith McAdam, one young white landlord who owns 30 properties in Cleveland, the ideal tenant "pays the rent relatively on-time, calls when stuff breaks, takes out the trash, and cleans up the yard." These are necessary conditions for profitability, but they also touch on landlords' moral understandings of citizenship and responsibility. These moral boundaries represent the foundation on which the paternalistic approach to poverty governance is built - legitimizing a wide range of reformative and exclusionary actions against tenants.

The Culture of Poverty \& The Responsibility to Pay Rent

The case of Franklin Dubicki, an owner of over 100 Baltimore row houses, illuminates the perceived cultural basis of landlords' moral evaluations. A fifty-year-old white man, Franklin was not shy about sharing his opinion on the black poor. He grew up in one of the neighborhoods where he now rents properties. His family "held out," but once enough black families moved in the block was busted, and they moved to the suburbs (cf. Orser 1997). In his work as a landlord, Franklin deals with Baltimore's poor on a daily basis, pursuing them for late rent, censoring them for not cutting their grass, and fretting over where they dispose of crab shells: "Well, you try to talk to them and reason with them, and hopefully some of it will sink in but a lot of times it just doesn't. You know, the tree has already grown pretty crooked." 
From a financial perspective, extracting profit from a business catered to poor people is difficult. As one landlord put it, it's like drawing "blood from a stone." Tenants' ability to pay depends on the vicissitudes of the low-wage labor market. With the defunding of cash welfare, more families rely on minimum wage employment, leading to income fluctuation and periods of extreme deprivation (Edin and Shaefer 2015; Western et al. 2012). Tenants bear the brunt of this insecurity, but it affects landlords as well, whose income streams depend on their tenants'.

Franklin, however, insisted that his high rent delinquency rate is not because his tenants cannot afford to pay, but rather because they fail to budget: “They're spending their rent money. And once it's spent, it's spent, and well, 'Mr. [Franklin], he's a nice guy, we'll push it, I'll pay him next month.' They don't think like you and I think." Franklin went on to explain that his tenants' lack of financial responsibility isn't their fault; it's just their "upbringing":

They weren't brought up like us - I mean I don't know you two [the interviewers] but ... I was raised in a decent background. Most of them aren't. ... the issue with a lot of these racially challenged people... the male role model was nonexistent... And you've got to feel sorry for a lot of them really, but nevertheless a lot of these problems have resulted from them. And some people call them generational, I don't know, it might be multigenerational. But they don't think like us.

Franklin's belief that his tenants don't know how to be good tenants is linked to their race. Far from a description that referenced structural disadvantage, Franklin used the term "racially challenged" to denote a perceived intergenerational cultural disadvantage that supports his sense of individual responsibility.

Over 60 percent of landlords drew on similar articulations of the culture of poverty to explain and understand their behavior. Generally framed as their realist notion of "ghetto life," our respondents painted images of "neighborhoods with people lined up at 8 o'clock in the morning at the corner place to get their bottle of liquor," and families that "live a transient life" 
with "no roots" and who have "a whole different mindset." These tenants, landlords believe, require a special level of scrutiny.

\section{Using Moral Evaluations to Find the Right Tenant}

Finding the right tenant is defined not just by who has the money, but also by who behaves well by using that money to pay rent on time, making the landlord's life easier. During the screening process, landlords can enlist specific tools such as criminal background checks, residential history checks, and credit checks. But landlords view themselves as caught in the classic problem of information asymmetry: beyond identifying a few "red flags" like prior evictions and criminal records, there is little documentation from which to distinguish between applicants, as few poor tenants have good credit and unblemished rental histories. Most landlords admit that they have no system with which to perfectly predict tenant quality, and so finding the right tenant comes down to a "gut feeling." What landlords call "gut feelings," sociologists might think of as moral evaluations or symbolic boundaries, i.e. distinctions of moral "worthiness" (Lamont and Fleming 2005; Lamont and Fournier 1992; Lamont and Molnar 2002; Lamont and Small 2008). What then, constitutes worthiness for landlords?

Landlords often base their opinion of a prospective tenant on how she dresses, whether or not she returns phone calls in a timely manner, how she parents her children, and the questions she asks (or does not ask) about the unit. ${ }^{i}$ Liam Fenwick, a white landlord in his sixties who has owned large number of properties in Baltimore since the 70s, likes to conduct small experiments to learn more about a tenant. He will give the tenant a list of the websites where they can access and print their own credit report for free, telling the tenant: "Here, you take care of this." $\mathrm{He}$ doesn't actually want the report, but if the tenant fails to produce, Liam takes this as a signal of limited self-efficacy: "If they can't do a simple task that I'm asking them to do, how can they do 
a bigger task of paying me the rent?" He claimed, "I'm not playing a trick, that's my way of doing things. I'm asking them to give me information, and if they can't that tells me that it wasn't meant to be."

But Liam admitted that his techniques are imperfect at best. He often has to rely more on "gut feelings" about tenants. Charley Vo, the owner of 40 units in an 80 unit property that he also manages, is a Vietnamese landlord who came to the U.S. fifteen years ago "looking for the land of opportunity." He agrees that often it comes down to a gut feeling. Sometimes, he says "you can't tell the difference [between a good and bad tenant]... you never know what you will get.”

\section{Transferring the Burden of Maintenance}

"Good" or "bad," once the tenant is selected their behavior can have enormous consequences for the landlord. When it comes to property maintenance, tenant behavior can create health risks, nuisance to the neighbors, pose a structural risk to the home, and incur costs to the landlord. Keith explained his frustration: "[Landlords] don't have any control. Our hands are totally tied... Like if they put their garbage out wrong, I get fined, if they don't cut their grass, I get fined, if they have litter there, I get fined...They fine you for anything. Like one time - you know they have those big garbage cans - The [tenants] put too much garbage in and the lid was sticking up like this much," Keith held up his thumb and index finder about an inch apart as if he were holding a quarter: "one-hundred dollar fine," he said (see also Greif 2018).

Tenant negligence can represent more than small fines. For the more economically fragile landlords, a large one-time expenditure can have significant financial consequences, disastrously undermining the profitability of their real estate holding. Matt and Katherine are a married couple who own 18 units together in Cleveland's Lakewood neighborhood. They have two kids and struggle financially to keep everything afloat. The day before Katherine gave birth to their 
first child, the couple received a water bill in the mail for over $\$ 10,000$. Matt recounts: "I sat on the couch and cried. We're going to go bankrupt. It was a nightmare.” Then Matt found out why the water bill was so high:

About three days later I was over at the building and this tenant comes out, and he was loony tunes huge, huge, 6' 4', 6' 5'. All he had - he had nothing in his apartment except a chair and a weight set in the living room. And a bible. But he tore the handle off the faucet in the kitchen and the water had been running and running and running and running. And he came out and says, "Oh, I've got a problem with my sink." I go in and I said, "How long has this been going on?" "I don't know." I flipped my lid because I knew damn well that's where all my money was. It was a nightmare.

Beyond the cost of the water, Matt expressed disdain for his tenant's negligence in failing to report the problem, believing him to be oafish, ignorant, and ultimately, irresponsible.

Tim Kozak owns 150 units across six properties in Cleveland built in the 1920s. Tim recounted a time when he visited a tenant living on the top floor of one of his buildings. $\mathrm{He}$ walked into the living room and saw a huge flap of the ceiling hanging down: "I mean the whole ceiling was collapsing because of the leaks." The problem is, Tim explained, "This is something that we're not going to know until tenants tell us ... We didn't know about it, so we couldn't fix it." Tim didn't hold the tenant financially responsible: "It's not his fault it was leaking, [but] he should have told me." Here, Tim rationalizes that the tenant's "personality" - or moral failing actually transmutes into financial liability for the landlord: "When a tenant doesn't care about the property — and again, it's the personality —if the person doesn't really care how they live — iit] may not get caught in time to get everything repaired before it causes excessive damage."

Landlords' perspectives of maintenance are complex. On the one hand, they resent tenants who frequently damage a unit or report small issues that the landlord expects them to repair on their own or simply tolerate. There are some cases where landlords may be counting on tenants not to report major problems out of fear of retribution or eviction, saving the landlord 
time and money. However, we find this to be true only in a minority of cases, and those who adopt this strategy wholesale tend to own lower-end properties nearing obsolescence.

On the other hand, some unrepaired small issues such as plumbing and roof leaks can turn into large expenses for a landlord down the road. Since landlords renting to subsidized tenants have to pass yearly inspections, they need to stay on top of maintenance issues. Thus, in addition to encouraging tenants to take responsibility for some repairs, landlords feel that getting them to report other kinds of maintenance issues is key for long-term profitability. Liam, for example, explained his instructions to call when there is a problem: "Most of them aren't going to call you unless it's a true emergency. I tell them, "You've got to call me. If you don't want to call me, email me, text me, do whatever - you know, send up a smoke signal, so that I know," With exasperation Liam exclaimed: "How many times do I have to tell you?"

Narratives of tenant agency (or lack thereof) are used as part of a moral revision to transfer responsibility. Framing their tenants as negligent for failing to report problems allows landlords to shift the burden of hazardous conditions off of their own shoulders. In Tim's account, the problem was not that the ceiling collapsed due to deferred maintenance on the roof, but rather that his tenant did not report the incident quickly enough. In a paternalistic framework, the landlord responds to the problem by "teaching" the tenant how to be better, promoting more timely reporting in the future. If this doesn't work, they evict. In this way, paternalism functions to transfer not only the financial burden, but also the moral burden of the repair from landlord to tenant.

Thus landlords' stories about poor tenants reflect more than mere frustration. These narratives, which embrace the ideal of personal responsibility while simultaneously positing a cultural explanation for behavior, are uniquely self-serving. Landlords perceive their tenants to 
be simultaneously pitiable — they do not know any better — and personally responsible—spending their rent money on recreation is a choice. This narrative gives the landlord a moral imperative to intervene in tenants' lives in a variety of exclusionary and reformative ways.

\section{Cultivating the "Good" Tenant: The Paternalist Mission}

While a good tenant cannot always be found, landlords argue, such a tenant may be created. This strategy is often defined as a broad civilizing mission, whereby landlords attempt to acculturate their tenants into the mores of those who are most profitable to house. Landlords in our sample invest time and energy to mold tenants into ideal renters, teaching them the moral value of paying their rent on time, caring for their homes, and interacting respectfully with management.

\section{The Moral Value of Paying Rent}

The paternalist management strategy focuses on shifting the narrative towards personal responsibility in order to promote timely rent collection. Landlords see tenants' difficulty paying rent primarily as a problem of values and education, and therefore focus on teaching them about prioritization and budget management. Like Franklin, Liam is perpetually flummoxed by his tenants" "priorities": "Good example: a tenant is not able to pay the July rent. But she certainly was able to pay for getting her transmission fixed." Liam tried to make sense of why: "I think it will really come down to the fact that some people can't budget their lives, it's that simple. It's an economic thing, maybe tied to a socioeconomic thing." Liam takes it upon himself to sit down and help tenants work out a budget for expenses and a payment plan to catch up on rent-owed.

Beyond financial education, landlords believe that they need to teach tenants about the consequences of not paying rent by maintaining strict and easy-to-follow rules. Mark Wheatly, the wunderkind co-owner of a large portfolio of hundreds of rental properties in Baltimore, told 
us about how important it is to be professional and consistent when teaching tenants how to behave: “Anything over $\$ 100$ we send to rent court. They quickly learn... you get hit with $\$ 30$ of court cost [plus] your $\$ 100$ push and it makes a lot of sense to get in here on the first." In Mark's view, landlords with high vacancy rates actually "create [their own] evictions" by "letting people get sloppy." In failing to train them to pay on time, Mark said, "they increase their own vacancy rate... We can't be selective about the rules, we're going to enforce them or we're not going to enforce them. There needs to be a regime, like you know, this is how we behave."

Mark's goal to teach his tenants how "we" behave is a long-term solution. He certainly wants his money, but repeatedly chasing debts worth as little as $\$ 100$ doesn't make sense aside from the role it plays in the larger acculturation project. Mark is not satisfied with constantly wielding the eviction stick; instead, he wants to instill moral habits.

Landlording as a "Ministry"

Devah Haskins, an African-American landlord in Baltimore, claims her 80 rental properties are the nicest in the city available to voucher recipients. Far from an idle boast, we observed the granite countertops, micro-tile backsplashes, hardwood floors, and recessed lighting firsthand while accompanying Devah on her daily routine. We asked her why she renovated above market when subsidized rents are capped. Devah explained that it allowed her "to get a better-quality tenant." Devah's business model is predicated on educating poor single mothers how to be better tenants; providing high-end amenities is just a part of this approach.

The investment Devah puts into renovation means that she needs to minimize turnover and maximize upkeep. Amenities are key to attracting the right tenant, as is Devah's screening process, which includes a 50-item questionnaire asking the same question multiple times in hopes of catching the applicant in a lie. But this is not enough. When a tenant gets behind on 
rent, Devah intervenes in their personal lives, trying to shift the behaviors that she feels are leading them astray - a process she refers to as "her ministry." In Devah's words, "It's a ministry for me because I don't treat tenants as a tenant... some only have high school diplomas, that really don't have the education, and so I feel that it's my job to educate them."

This education takes many forms, especially personal finance. Like Franklin and Liam, she rejects the idea that tenants don't pay simply for lack of money. Devah instead evangelizes proper budgeting. When one of her tenants was having trouble paying her water bill - the tenant's responsibility in the lease - Devah sat her down and explained: "the water bill is quarterly. Quarterly means every three months." She encouraged the tenant to set up a plan to pay monthly thus avoiding larger payments. But Devah doesn't stop there:

After teaching [about the water bills], most of them don't have checking accounts, so I educate them on how to get a checking account because a lot of them want to pay either cash or money order for their portion [of the rent]. And then with their children, I try to instill excellence in them because those are the things that I expect from my children, and so we have to set standards. But, a lot of it's just exposure, they come from broken homes and they haven't gotten that from their parents. So I just take them under my wing.

Here, Devah moves from a relatively mundane material problem - how to budget a quarterly expense - into a broad project of moral reform. Devah linked this mission to her own impoverished background and Christian faith, but she is also a shrewd businesswoman who stands to benefit from this "cultural education."

This dual reality of mission and business is illustrated most clearly at Christmas when Devah purchases presents for her tenant's children, while simultaneously insisting that they should value paying rent above all else:

Here's where education comes in. I had one [tenant] say "I know I'm late, but I got to get my children Christmas toys." So I said, "Let me ask you something. What do you think is more important to your children? Christmas toys or having a place to live to play with those Christmas toys?" I said "You have to get your priorities straight... You put so much emphasis on toys and gifts, it's not the right thing to do. Your rent needs to be paid 
by the fifth. Otherwise your children are not going to have any place to play with toys for Christmas."

Devah concluded, "So that's the ministry." Devah's double meaning of ministry—her Christian ministry, and her cultural ministry in financial education — is paradigmatic of paternalist management which infuses amoral tenant management techniques with moral imperatives. "They are like my children": "Section 8 Girls"

The paternalistic relationship between tenants and landlords goes beyond education. Landlords describe their poor tenants not just as incomplete citizens, but also as children. Charley is frequently in the position of resolving tenant disputes, and has learned how to deal with tenants when conflict erupts by thinking of them as less-mature versions of adults: "You know, most of my tenants are basically like my children.” And Keith surmised that sometimes, "You got to go babysit your tenant, it's like running a daycare." Keith means that he feels he has to constantly monitor and regulate his tenants' behavior, making sure they aren't too loud, they take the trash out regularly, and pay their rent on time.

This infantilization frame shapes landlord tactics for dealing with conflict. Ben Roth, a white landlord who has owned a large number of properties in the Baltimore market for years, recounted a time when a woman moved into one of his units who was in his words, "a little ADD," calling him constantly with problems and questions and bothering the neighbors by making noise in the middle of the night. With no formal grounds for eviction Ben was at his wits end. He came up with a subtler tactic: he called her father. Ben did this with the hope that the father might have some influence over his daughter's behavior, telling the man: "Listen, your daughter is being a pain in the ass. Can you get her out of my house? I'm giving you all your money back, every bit of it, including the security deposit and an extra $\$ 200$ to move. Just get her out of my house." Together, the two men discussed the young woman's behavior, and came 
up with a plan. The tenant's father warned his daughter to "shape up." Since this talking-to Ben said, "she's been the best tenant for five years now, because I ratted her out."

For Ben, Charley and other landlords, this infantilization takes on a distinctly gendered dynamic. Charley believes that male partners represent predatory influences, who use his tenants for free housing while offering little in return:

There are people who are living off those Section 8 tenants. Could you believe it? A girl who have two children, you know, out of wedlock of course, and has a voucher. And next thing that you know is that there's a lot of guys who preying on her. Why? Because she provides them good place to stay.

Charley, who was not the only landlord to refer to them as his "Section 8 Girls," is both pitying and disdainful of these tenants. He was also vigilant about the risk he feels their partners pose.

The parent-child dynamic was amplified in Dallas, where half of our respondents were female property managers at large apartment complexes. These women frequently referred to themselves as the "mother" of their co-ethnic tenant populations, and were deeply involved in resolving disputes and helping tenants manage their daily lives. The communal swimming pools, nearly-ubiquitous even in the low-income Dallas complexes, were often located directly outside their office windows, allowing for a protective and disciplinary eye on the swimmers.

Debbie Murphy is a property manager with over thirty years of experience in the Dallas market. She is white, a divorced grandmother in her fifties, sports a friendly head of red curls, and currently manages 5 buildings and nearly 600 tenants across them. Debbie cares deeply for her tenants. Like Devah, Debbie's dedication makes the work more than just a job: it's a mission: “God gave me a burden for poor people who are down and out. It's very rewarding to be a property manager, because you can help people. That motivates my life. To encourage others." Seeing herself as a caring mother whose children have gone astray, Debbie has a "tough love" approach to her tenants: "The key to a successful program is a tough manager." 
This is my heart for my residents. You work so much harder for the money that you pay your rent with than I have to work ... You deserve the utmost respect and treatment. [But], if you come in here and you threaten me, you're going to have the police here within just a few minutes. And you will be arrested, and I will press charges. But as long as you can keep your tone even, and we can deal as adults with this, I'm here to serve you.

Some landlords like Debbie take a protective and advisory role, offering unsolicited advice about how to keep unwanted men away, and enforcing strict rules pertaining to non-lease-holding adults in the home. This role allows landlords to maintain control over tenants, while justifying it with the idea that they are offering valuable protection and advice.

But Debbie explained her view that some of her female tenants just cannot be helped:

“The women seem to be attracted to the wrong kind of men. They're not on the lease, and they have felony convictions or something else, or maybe they're a child molester... I don't know how much you know about co-dependency, but [some women] cannot break off. It's their comfort zone to be abused. It's all they know." In one recent case, she had a tenant whose nonlease-holding boyfriend turned out to be a child molester. "I had to post his picture in the laundry rooms. I had to warn people... You have a child molester here.” If the tenant does not get rid of the boyfriend, Debbie says, "I have to evict her." But she feels that women like this leave her no choice: "They shoot themselves in the foot by bringing these guys in," she remarked with a sigh.

Like Debbie, most of the property managers in Dallas cared deeply for their tenants and worked hard to maintain a clean and safe living environment. The flip side of this paternalist investment in tenants' personal lives, however, is that it legitimates surveillance above and beyond the professional relationship.

\section{Beyond Benevolence: The Specter of the "Professional Tenant"}

Landlords are clear in their view that some tenants are beyond moral intervention. While intersecting narratives of irresponsibility and gender fragility embolden landlords' intervention 
into tenants' lives, there is another narrative that legitimizes intervention beyond "tough-love." Landlords are not always supportive; they are sometimes punitive. Landlords legitimize this based on the belief that there is class of tenants who are constantly looking to "put one over" on them. This largely-fictionalized "professional tenant" is a master manipulator, duping landlords into accepting him or her as a tenant and then taking advantage of tenant-friendly eviction laws to live rent-free for months. Joan Carter, a white woman who owns two rental properties in the Baltimore suburbs, explained that she doesn't own property in high-poverty neighborhoods because she is afraid of this "professional tenant." These are people, she said, are "people who are professional renters. When you get them in, pay their first month's rent and then they have you for six months." Landlords are always on the lookout for a "professional tenant," even though few report having actually encountered one. In the rare case where landlords feel they are stuck with such a tenant, they often switch from a reformist strategy to a punitive one. We argue that this punitive strategy is part of paternalism: when teaching does not work, landlords turn to surveillance, threat, and sometimes expulsion.

Supervision, Surveillance, Coercion, and the Threat of Eviction

Many landlords proactively collect information about their tenants to be used in a variety of ways to protect themselves against the specter of the professional tenant. Charley explained that part of his job is "constant supervision. You need to figure out who is good, who is bad, who's making trouble, who's not." For example, when there is a crime in the development, he knocks on residents' doors to see what people know, telling them, "You need to let me know. Because I cannot help you if you cannot help me. It's a helping each other situation.”

When Charley first took over the 80-unit apartment complex where he is the property manager, about half of the units were vacant, and crime was rampant. Charley had a hunch it was 
coming from the tenants themselves. One of his newest tenants was a middle-aged African American woman:

When she signed the lease, she didn't mention anything about her boys. She move in, the boys move in as well. Now, I knew about it, but I'm not going to do anything. Because hey, you know sometime you let it go. Next thing I know, one of my tenant was broken into, and they lost TV and a couple more things.

Meanwhile, one of the new tenant's sons reported that a strange man had paid him 10 dollars to help him load a TV into his car. He was eager for some pocket money and so had agreed to help the man, but then realized he'd better come and report it. Charley figured someone in the complex must have seen what this stranger looked like. When he started asking around, "people were telling me that they saw the boy hauling electronic stuff around. They don't know exactly what's going on, but they're saying, "how come I keep seeing those boys with electronic things?" I realized that there's no one coming here to steal anything. It's them. They concocted the story." Charley wanted to send a clear signal to other residents that "I don't condone that kind of activity around here." So, he immediately began the process to evict the woman and her boys, using a late rental payment from the previous month to justify the eviction.

The information that landlords garner from neighbors can be used to control undesired behavior in the complex, which Charley says has helped him gain residents' further trust and compliance. Charley has trained his tenants to report noise, theft, and other problems with neighbors. It took some work, but Charley claims that his tenants now trust him and come to him on their own accord: "It's myself and the maintenance man, we're the only two that take care of things around here. So, I guess the trust stems from the fact that I take care of them." This trust, in turn, allows landlords to monitor tenants and collect useful information.

Landlords have more than just information to keep tenant behavior in line. For tenants receiving voucher subsidies, landlords have additional leverage. Mark explained how the threat 
of losing the voucher prompts cooperation with landlords' expectations for behavior: "That's a life event, losing 1,000 dollars a month. So, they behave." Mark continued:

If you give them the opportunity, they're actually very good tenants; when they stay for six years ... And we can actually make money being good landlords when we're able to see that kind of tenancy duration. We can then make the business decision to invest and put an extra 30, 40 thousand dollars into lead paint abatement and upgrades and central air and all the stuff you want to put in houses.

The kind of cooperation Mark is referring to isn't merely adhering to program rules - it also refers to conforming to landlord expectations for tenant behavior such as being quiet and courteous, renewing the lease rather than moving on, fixing problems themselves rather than "bothering" the landlord. Mark's words make clear how this power dynamic is linked to paternalism. The coercive threat of voucher loss merges with giving tenants "the opportunity" to be good - a turn of phrase reflecting how tenant training is connected to the landlord's punitive authority. This good behavior, in turn, allows him to "give back" to his tenants by removing lead from their homes and fixing their central air, which he articulates as a reward for his tenants' good behavior. He claims that increased length of tenancy enables landlords to "make money being good landlords."

Moral evaluations of tenants are also key when it comes to eviction. As economic actors, landlords describe their approach to the eviction process in terms of profit maximization. In this sense, eviction solves a worst-case problem—a non-paying tenant- but it comes with a variety of additional costs: kicking out a tenant means being ready to absorb the costs of turning over the unit, including a period of vacancy. At best, this entails touching up paint, making repairs, replacing or cleaning the carpet, and forgoing rent until a replacement is found. For this reason, landlords in all three cities work hard to avoid executing an eviction. But by redefining renters as 
debtors - both in their minds as well as through filing for eviction legally—landlords are able to leverage the power of the state to get tenants to pay up, or leave (Garboden and Rosen 2019).

Thus, landlords translate moral categories into a legal category, initiating the eviction process as a type of behavioral corrective. The process of evicting reframes late rent payments as the tenant's moral failing rather than a structural reality, legitimating alternative and sometimes extra-legal strategies of financial extraction. This means that it can be beneficial for landlords to house tenants in small amounts of arrearage. Landlords understand that tenants who are behind on their rent are less likely to advocate for their legal rights regarding housing quality and code enforcement. Moreover, if a late rent case is active against a tenant, a landlord can use that debt as a cause for a nearly automatic eviction if they wish to remove the tenant for other reasons.

Eviction is a case where we see things switch from reform to exclusion. Some landlords switch more quickly than others. But generally, they agree that carrots work better than sticks in terms of maintaining a profitable business.

\section{Strategies across the Sample}

Despite the highly racialized and racist language used by our respondents, we see little significant difference in the way that black, white, Asian, and Hispanic landlords approach tenants. For example, we see no differences in the frequency with which black and white landlords use a "culture of poverty" framing to understand their tenants. These findings are in line with previous work, for example on welfare caseworkers, suggesting that black caseworkers are no less biased towards clients of color than their white counterparts (Gooden 1998). We interpret this to mean that race alone does not structure a landlord's approach to his tenants, but rather, the intersection of race, class, and gender form a composite stigmatized identity for tenants. Irrespective of racial background, landlords have, by and large, internalized the notion 
that they know best. They embrace the idea that their tenants - many of whom are female, black, and poor - are incomplete citizens who rely on government support and would benefit from the landlord's guiding hand.

A review of recent literature would suggest that landlords' primary strategy for managing unprofitable tenants is exclusion-including the processes of screening based on eviction history, and evicting tenants who are late in rent. This strategy is omnipresent throughout our sample.

Only 11 landlords claimed to never have evicted a tenant and these were typically landlords with very small portfolios or portfolios that were more skewed towards higher-income renters. But as we have argued, our data shows that exclusion is only one part of a broader paternalistic paradigm for landlord-tenant relations.

In fact, only 13 percent of our respondents described themselves as managing predominantly through exclusion. A few of these individuals expressed purely revanchist motivations for their management practices, framing their landlord-tenant relationships in terms of conflict and animosity. The Farmer brothers in Cleveland represent an edge case of this segment. They declined to be recorded by our fieldworkers for legal reasons, boasting openly about blatantly illegal practices such as removing doors from units, shutting off electricity and heat, and knowingly allowing their properties to fall into disrepair. The other type of landlord relying on predominantly exclusionary tactics were property managers who specialized in turnover, the wholescale replacement of one tenant type with another in order to upgrade or downgrade a unit's market position. While for these landlords, eviction was profitable within their particular niche, for most it was not the first line of defense.

The rest of our respondents relied on subtler combinations of reform and exclusion, in other words, carrots and sticks. Notably, 83 percent of the sample worked to avoid eviction when 
it was profitable to do so, working out payment plans with tenants and accepting late and partial payments. For the 87 percent of respondents who did not rely solely on exclusion, the level at which they implemented strategies of reform varied dramatically. Reformist tactics took many forms, ranging from assistance with budgeting to coercive interventions of surveillance and threat. For some, reform was a reactive strategy, implemented to keep a tenant in a unit rather than losing the revenue involved an eviction. For others, it represented a coherent proactive strategy requiring the investment of significant resources.

The prevalence of reform was directly related to the presence (or absence) of a professionalized landlord class. While large professional landlords exemplified some of the strongest exclusionary practices, they also exemplified the most proactive attempts at reform. As described above, these were the managers of large low-income housing complexes in Dallas, the large corporations specializing in voucher families in Baltimore, and a few of the better capitalized landlords in Cleveland. For these landlords, the first line of defense is to address problems with paternalism's velvet glove, by investing time and resources in changing tenant behavior to make them more profitable to house, and eviction is usually reserved as a failsafe strategy when training and behavioral strategies fail.

There is also important regional variation across the sample. In Baltimore, nearly all of the more professionalized landlords used reform tactics (94 percent) compared to Dallas where about two-thirds (67 percent) and Cleveland where just under half (46 percent) adopted this strategy. The variation across our cases allows us to identify three conditions that may drive these cross-city differences: the nature of the housing stock, the regulatory environment, and the profitability of renting to subsidized tenants. 
Baltimore represents an ideal site for reformist paternalism for two reasons. First, tenant rights advocates have had more success in housing court reform there than in either of the other cities (Hatch 2017). Unlike in Texas and Ohio, tenants in Maryland have a four-time "right to redemption," meaning they can avoid eviction by paying back rent up until the date they are put out. In Baltimore, the housing court and sheriff's department are overwhelmed, resulting in long delays. These factors combine to dramatically increase the costs of a purely punitive strategy. Second, and perhaps more importantly, due to a disparity between voucher and market rents, many large landlords with low-end properties in Baltimore adopt specific strategies to pursue voucher tenants (Garboden et al. 2018; Rosen 2014). The voucher program not only provides those landlords with additional leverage over their tenants, it makes housing stability, and thus paternalism, more valuable by guaranteeing a substantial proportion of the rent.

In Dallas, where the regulatory environment is pro-business and evictions are easier than in Baltimore or Cleveland, the level of paternalism is influenced by the built environment. The low-end market in Dallas is dominated by large apartment complexes owned by sizable trusts and staffed by professional managers. As we show, these property managers (who in our sample were all women and co-ethnic with their tenants) work on site, interacting with tenants and investing resources in their stability. Not only is occupancy rate an explicit evaluation metric used by these companies, but the proximity, both social and physical, results in a more paternalistic approach by these managers.

Cleveland has none of these components. Despite a push for reform, the eviction process in Ohio remains pro-business (Hatch 2017), the incentives to rent and retain voucher holders are almost nonexistent, and few properties have on-site management. These factors, combined with 
the city's poverty rate, push just over half the strategic landlords into revanchist management strategies, focused on eviction.

\section{DISCUSSION}

There is a long tradition of examining how, where, and with what consequences the poor are regulated (Katz 1997; Lipsky 1980; Piven and Cloward 1993; Schram 2006; Soss et al. 2011; Wacquant 2009): "Socially marginal populations cannot be safely ignored for long; they must be governed" (Schram, Fording, and Soss 2008). We argue that with the increasing reliance on the private market to house the poor, landlords are a key but under-examined actor in this effort. As in neoliberal poverty governance more broadly, we find landlording is defined around a dual disciplinary agenda that is employed in the service of promoting tenant reform and responsibility, with exclusionary consequences for those who do not conform (Soss et al. 2011).

Landlord paternalism cultivates the ideal tenant first through behavioral modification, "nudging" the poor, and incentivizing them to change their own behavior. When behavioral incentives fail, paternalism motivates tenant compliance by relying on more disciplinary techniques of surveillance, facilitating threat, intimidation, and eviction. This two-pronged approach of training and incentives on the one side, and surveillance, threat, and punishment on the other, is emblematic of the neoliberal paternalist era (Soss et al. 2011). We see this manifested most clearly in the case of housing vouchers - the bureaucratic extension of the state gives landlords tools to threaten punishment though eviction and revocation of the voucher (Garboden and Rosen 2019). Theorizing landlords' paternalistic management of their tenants as part of a larger project of poverty governance highlights practices with important implications for tenants that might otherwise go unseen. Researchers and policymakers should attend not just to the more obvious punitive tactics such as eviction or voucher revocation, but also to the 
subtler ways in which landlords shape tenant behavior through incentives, training, surveillance, and threat.

We argue that landlords draw on moral frames to understand and interact with their tenants, and to construct their own role as the purveyors of affordable housing. Landlords defer responsibility for property maintenance to their tenants, who they frame as ignorant and negligent. Landlords espouse twin narratives about female tenants, or "Section 8 girls," as helpless victims preyed upon by male partners on the one hand, and as conniving "professional" tenants on the other. Reflecting the self-contradictions inherent in the political discourse around social support, landlords view their voucher tenants both as a special case of living off the system and simultaneously of vulnerability and need. These stereotypical narratives of the black underclass - the incompetent child, the helpless single mother, and the amoral villain - serve primary functions in the work of landlords. First, they make poor tenants an appropriate target

for training and acculturation. Second, the narratives shift the market position of the tenant away from consumer of housing, with all the inherent rights of negotiation, boycott, and consumption. Instead, poor tenants - even those paying out of pocket - are seen as housed by the benevolence of the landlord, allowing far more interference into their daily lives than otherwise appropriate.

\section{CONCLUSION}

As much as our analysis has revealed similarities in the paternalisms practiced by landlords and civil servants, there also exist meaningful differences. As noted in the introduction, the private landlord sits at the intersection of two macro-phenomena: the paternalistic trend in poverty governance and the neo-liberalization of domestic housing policy. The landlord, as a profit seeking entity, is constrained by a different set of forces than the public bureaucrat or the government contractor. A bureaucrat or contractor may wield paternalism because it is an 
explicit part of public policy, because it aligns with her personal ideology, or because it represents a necessary adaptation to being asked to do more with less. But the landlords in our study employ paternalist techniques because they represent a path to profitability.

The convergence here is certainly not coincidental. If a nation attempts to "run government like a business," it is not surprising that other researchers would see in the behavior of civil servants what we see in the behavior of landlords. But there is an important distinction between operating like a business and actually being a business. While a more thorough examination of this distinction is warranted in future research, here we propose the following broad categorical distinctions: guardrails, motivation, and consistency.

In most cases, there exist guardrails that constrain the paternalism of civil servants and contract workers. While the literature is rife with examples of how implementers push against and sometimes bend these guardrails, there remain hard limits to their ability to do so. A contractor, for example, cannot simply cease to provide benefits without violating her contract. A civil servant cannot personally relocate his place of work in order to achieve more favorable tax conditions. In contrast, landlords are able to do so with only minimal legal protections for the tenants they serve.

The second difference is motivation. New research documents how the state creates and leverages "administrative burdens" that lower program rolls and make it harder for disadvantaged groups such as the poor, people of color, and persons with disabilities to take advantage of government programs (Herd and Moynihan 2019). Private landlords who rent through the voucher program create similar administrative hurdles, however they may do so with a slightly different motivation. Rather than indiscriminately lowing the rolls, landlords use these administrative burdens (for example, extra paperwork, lengthy applications, and home visits) as 
a screening mechanism to weed out supposedly "undesirable" tenants (Rosen, Garboden, and Cossyleon 2019). Their motivation is not to save money, but to find the most "desirable" tenant, furthering their own bottom line.

This speaks to the most significant difference between public and private paternalism: consistency. In most jurisdictions, landlords can cease to implement subsidized housing policy without any repercussions. Whether that means refusing to accept vouchers, converting rental properties to condos or vacation rentals, or wholesale sell-offs of their portfolios, private paternalists can cease to be paternalists whenever they choose to do so, shifting to exclusively exclusionary tactics when the market encourages them to do so.

When compared to the exploitative slumlords who dominated urban rental housing in the era of de jure segregation (and remain active in some markets today), the paternalists may appear less cruel, but they are no less self-serving. The paternalistic civilizing mission is designed to further the interests of the landlord, often at the expense of the tenant. The moral education of tenants is primarily an attempt to reduce financial losses from unpaid rent, property vandalism, and conflict. But respondents' legitimizing narratives are intimately tied up with understandings of race, class, and culture, incorporating narratives of personal responsibility and teaching tenants how "we" behave.

Power matters too. When the benevolent tools of teaching and training fail, the paternalistic relationship's exclusionary face helps maintain a power imbalance. Legal advocates have long bemoaned the difficulty tenants have exercising their rights over the landlord's and have sought legal remedies such as eviction reform. However, even when tenants have legal rights, they are often eclipsed by their lived relationship with the landlord. In a theoretically competitive market, some power rests with the consumer who can choose whether or not to 
purchase housing services from a particular owner. Given the low levels of demand in cities experiencing population decline, one might expect that market power would shift toward the tenant. While competition between landlords may have reduced reckless exploitation, systems of threat and obligation prevent tenants from exercising the full breadth of their rights. In this way, paternalism functions to maintain power where it has historically resided: with the property owners. The turn to housing vouchers as the predominant method of housing the poor exacerbates this power imbalance since landlords play a key role in this type of housing,

The between-city comparison described above also suggests that there are policy interventions that can lead landlords to adopt more reformist than exclusionary strategies. As the costs related to eviction rise (through expanding laws that give right to redemption and right to counsel, for example), landlords will likely do one of two things. On the one hand, they may shift the exclusionary moment from eviction to screening, becoming less willing to accept tenants for whom they believe moral reform is necessary. However, our data suggest that many landlords struggle to predict the profitability of a tenant before they are in the unit. This, in turn, will push them toward more reformist techniques of management.

Landlords' reliance on reform rather than exclusion can mitigate some of the dire costs of residential instability, thereby improving the lives of poor tenants. However, this should not be considered the final objective of policy. Poor tenants should not be excluded from safe housing, but neither do they need to be reformed into the landlord's ideal tenant. Only by empowering tenants as consumers of housing, rather than incomplete citizens in need of instruction, can we promote equity in urban housing markets. This, unfortunately, represents a sort of social policy that the U.S. government has been moving away from for quite some time. 
Whether landlords tend toward tactics of reform or exclusion, both are evidence of a larger trend toward poverty governance in housing. In this paper we 1) argue for the importance of paying attention to the role that housing - and in particular landlords - play in poverty governance, 2) demonstrate how landlords draw on moral categories to define and frame their tenant's behavior, shifting responsibility onto the tenants, and 3) show how these moral evaluations translate into tenant management strategies involving both the stick and the carrot. Future research should continue to explore the important role that landlords play in poverty governance and how this affects the lives of poor renters. This research is limited in that it was conducted with a focus on landlords, rather than directly observing the relationship between landlords and their tenants. More work is needed linking landlord strategies and tactics directly to outcomes and experiences for tenants.

What are the implications of landlord paternalism? For some types of tenants, namely those who are most profitable to house, this transition has been beneficial. A poor family with a housing voucher is now very desirable to certain urban landlords. And to the extent that landlords make improvements to increase length of tenure, a certain segment of renters - those who are "desirable" to landlords - may experience the benefits of housing stability and quality. But these "desirable" tenants represent only a portion of the urban rental market. The steady increase in rent to income ratios combined with heightened employment instability have generated a tenant class who is less profitable to house in the private rental market. Far from the conniving professional tenants in which our landlords so fervently believe, these families face structural barriers that have long put them at a disadvantage in their housing search. For these families who face persistent housing instability, paternalism does not offer any advantages because they experience only the punitive side of it (see Desmond 2016). As more and more 
landlords chase the upper echelon of tenants, less and less stable and affordable quality housing is available to the modal poor renter. In the ever-privatizing modern American housing market, it is these neediest renters - who are for a number of reasons beyond the reach of their landlord's "ministry"- who are increasingly left out in the cold. 


\section{Works Cited}

ACS. 2014. American Community Survey Data. Washington, DC: U.S. Census Bureau.

Banfield, Edward C. 1970. The Unheavenly City. Boston, MA: Little, Brown.

Blackmar, Elizabeth. 1991. Manhattan for Rent, 1785-1850. Ithaca: Cornell University Press.

Chaskin, Robert J., and Mark L. Joseph. 2015. Integrating the Inner City: The Promise and Perils of Mixed-Income Public Housing Transformation. Chicago, IL: University of Chicago Press.

Citizens Planning And Housing Association of Baltimore (CPHA). 1941. Blighted Areas and the Defense Program. Baltimore, MD: Maryland State Planning Commission.

Collins, Patricia Hill. 1990. Black Feminist Thought: Knowledge, Consciousness, and the Politics of Empowerment. New York: Routledge.

Collins, Patricia Hill. 2015. "Intersectionality’s Definitional Dillemmas.” Annual Review of Sociology 41(1):1-20.

Connolly, N. 2014. A World More Concrete: Real Estate and the Remaking of Jim Crow South Florida. Chicago: Chicago University Press.

Corbin, Juliet, and Anselm Strauss. 1990. Basics of Qualitative Research: Techniques and Procedures for Developing Grounded Theory. LA: Sage.

Crenshaw, Kimberle. 1989. "Demarginalizing the Intersection of Race and Sex: A Black Feminist Critique of Antidiscrimination Doctrine, Feminist Theory and Antiracist Politics." University of Chicago Legal Forum (1):139-67.

Dedman, D., D. Gunnell, Davey Smith, and S. Frankel. 2001. "Childhood Housing Conditions and Later Mortality in the Boyd Orr Cohort." Journal of Epidemiology \& Community Health 55(1):10-15.

Desmond, Matthew. 2012. "Eviction and the Reproduction of Urban Poverty." American Journal of Sociology 118(1):88-133.

Desmond, Matthew. 2016. Evicted: Poverty and Profit in the American City. New York City: Crown.

Edin, Kathryn, and Luke Shaefer. 2015. Two Dollars a Day: Living On Almost Nothing In America. New York: First Mariner Books.

Engels, Friedrich. 1845. The Condition of the Working Class in England. Reissue edition. edited by D. McLellan. New York: Oxford University Press. 
Evans, G. W. 2003. "The Built Environment and Mental Health.” Journal of Urban Health: Bulletin of the New York Academy of Medicine 80(4):536-55.

Fields, Desiree. 2015. "Contesting the Financialization of Urban Space: Community Organizations and the Struggle to Preserve Affordable Rental Housing in New York City." Journal of Urban Affairs 37(2):144-65.

Galster, George C. 2008. "U.S. Housing Scholarship, Planning, and Policy since 1968: An Introduction to the Special Issue." Journal of the American Planning Association 74(1):5-16.

Garboden, Philip ME, Eva Rosen, Stefanie DeLuca, and Kathryn Edin. 2018. "Taking Stock: What Drives Landlord Participation in the Housing Choice Voucher Program." Housing Policy Debate 28(6):979-1003.

Garboden, Philip, and Eva Rosen. 2018. "Talking to Landlords." Cityscape: A Journal of Policy Development and Research 20(3).

Garboden, Philip, and Eva Rosen. 2019. "Serial Filing: How Landlords Use the Threat of Eviction." City \& Community 18(2):638-61.

Gasper, Joseph, Stefanie DeLuca, and Angela Estacion. 2010. "Coming and Going: Explaining the Effects of Residential and School Mobility on Adolescent Delinquency." Social Science Research 39(3):459-76.

Gibson, Campbell. 1998. Population of the 100 Largest Cities and Other Urban Places in the United States: 1790 TO 1990. Washington, DC: U.S. Census Bureau.

Gilderbloom, John I. 1985. "Social Factors Affecting Landlords in the Determination of Rent." Journal of Contemporary Ethnography 14(2):155-79.

Gilderbloom, John I. 1989. "Socioeconomic Influences on Rentals for U.S. Urban Housing: Assumptions of Open Access to a Perfectly Competitive 'Free Market' Are Confronted with the Facts." American Journal of Economics and Sociology 48(3):273-92.

Gilderbloom, John I., Lin Ye, Matthew J. Hanka, and Kareem M. Usher. 2009. "Intercity Rent Differentials in the U.s. Housing Market 2000: Understanding Rent Variations as a Sociological Phenomenon." Journal of Urban Affairs 31(4):409-430.

Goetz, Edward G. 2011. "Where Have All the Towers Gone? The Dismantling of Public Housing in U.S. Cities." Journal of Urban Affairs 33(3):267-87.

Goetz, Edward G. 2013. New Deal Ruins: Race, Economic Justice, and Public Housing Policy. Ithaca, NY: Cornell University Press.

Goetz, Edward Glenn. 2003. Clearing the Way: Deconcentrating the Poor in Urban America. Washington, D.C.: The Urban Institute. 
Goldfeld, Abraham. 1940. The Diary of a Housing Manager. Fournier Press.

Gooden, Susan Tinsley. 1998. "All Things Not Being Equal; Differences in Caseworker Support Toward Black and White Welfare Clients." Harvard Journal of African American Public Policy 4:23-33.

Green, Howard Whipple. 1930. Population Characteristics by Census Tracts, Cleveland, Ohio. Cleveland, OH: The Plain Dealer Publishing Company.

Hackworth, Jason. 2007. The Neoliberal City: Governance, Ideology, and Development in American Urbanism. Cornell University Press.

Hanushek, Eric A., John F. Kain, and Steven G. Rivkin. 2004. "Disruption versus Tiebout Improvement: The Costs and Benefits of Switching Schools." Journal of Public Economics 88(9-10):1721-46.

Hartman, Chester, and David Robinson. 2003. "Evictions: The Hidden Housing Problem." Housing Policy Debate 14(4):461-501.

Hatch, Megan E. 2017. "Statutory Protection for Renters: Classification of State LandlordTenant Policy Approaches." Housing Policy Debate 27(1):98-119.

Herd, Pamela, Thomas Deleire, Hope Harvey, and Donald Moynihan. 2013. "Shifting Administrative Burden to the State: The Case of Medicaid Take-Up." Public Administration Review 73(1).

Herd, Pamela, and Donald P. Moynihan. 2019. Administrative Burden: Policymaking by Other Means. Russell Sage Foundation.

HUD. 2014a. "Low-Income Housing Tax Credit (LIHTC) Data."

HUD. 2014b. Status of HUD's Rental Assistance Demonstration (RAD) Evaluation and Results to Date. Washington, D.C.: Office of Policy Development \& Research, U.S. Department of Housing and Urban Development.

HUD. 2016. A Picture of Subsidized Households 2016. U.S. Department of Housing and Urban Development.

Ioannides, Yannis M., and Stuart S. Rosenthal. 1994. "Estimating the Consumption and Investment Demands for Housing and Their Effect on Housing Tenure Status." The Review of Economics and Statistics 127-141.

Jackman, Mary R. 1994. The Velvet Glove: Paternalism and Conflict in Gender, Class, and Race Relations. Berkeley, California: University of California Press.

Jerolmack, Colin, and Shamus Khan. 2014. "Talk Is Cheap: Ethnography and the Attitudinal Fallacy." Sociological Methods \& Research 43(2):178-209. 
Joint Committee on Negro Housing. 1951. Toward Better Understanding: Mutual Good Manners and Simple Courtesy Promote Inter-Racial Understanding. Dallas, TX: Dallas Inter-Racial Committee.

Katz, Michael B. 1997. Improving Poor People. Reprint edition. Princeton, N.J.: Princeton University Press.

Kusmer, Kenneth L. 1976. A Ghetto Takes Shape: Black Cleveland, 1870-1930. Urbana: University of Illinois Press.

Lamont, Michèle, and C. M. Fleming. 2005. "Everyday Antiracism.” Du Bois Review 2(1):2943.

Lamont, Michèle, and M. Fournier. 1992. Cultivating Differences: Symbolic Boundaries and the Making of Inequality. Chicago: University of Chicago Press.

Lamont, Michèle, and V. Molnar. 2002. "The Study of Boundaries in the Social Sciences." Annual Review of Sociology 167-195.

Lamont, Michèle, and Mario Luis Small. 2008. "How Culture Matters: Enriching Our Understanding of Poverty." Pp. 76-102 in The Colors of Poverty: Why Racial and Ethnic Disparities Persist, edited by A. C. Lin and D. R. Harris. New York, NY: Russell Sage Foundation.

Landis, John D., and Kirk McClure. 2010. "Rethinking Federal Housing Policy." Journal of the American Planning Association 76(3):319-348.

Lipsky, Michael. 1980. Street-Level Bureaucracy: Dilemmas of the Individual in Public Service. New York: Russell Sage Foundation.

Lutz, Helma, Maria Teresa Herrera, and Linda Supik, eds. 2011. Framing Intersectionality: Debates on a Multi-Faceted Concept in Gender Studies. Burlington, VT: Ashgate.

Main, Thomas. 1997. "Homeless Men in New York City: Toward Paternalism through Privatization." in The New Paternalism: Supervisory Approaches to Poverty, edited by L. Mead. Washington, DC: Brookings Institution Press.

Mallach, Alan. 2006. Bringing Buildings Back: From Abandoned Properties to Community Assets. Rutgers University Press.

Markowitz, Gerald, and David Rosner. 2013. Lead Wars: The Politics of Science and the Fate of America's Children. University of California Press.

Massey, Douglas S., and Nancy A. Denton. 1993. American Apartheid: Segregation and the Making of the Underclass. Harvard University Press.

Mead, Lawrence, ed. 1997. The New Paternalism: Supervisory Approaches to Poverty. The Brookings Institution Press. 
Milward, Brinton, and Keith Provan. 2000. "Governing the Hollow State." Journal of Public Administration Research and Theory 10(2):359-80.

Moore, Colin D. 2017. American Imperialism and the State, 1893-1921. Cambridge, UK: Cambridge University Press.

Muhammad, Khalil Gibran. 2011. The Condemnation of Blackness. Cambridge, MA: Harvard University Press.

Orser, W. Edward. 1997. Blockbusting in Baltimore: The Edmondson Village Story. Reprint edition. University Press of Kentucky.

Osborne, David, and Ted Gaebler. 1993. Reinventing Government: How the Entrepreneurial Spirit Is Transforming the Public Sector. New York: Plume.

Pager, Devah. 2003. "The Mark of a Criminal Record." American Journal of Sociology 108(5):937-975.

Patterson, James T. 1981. America's Struggle against Poverty in the Twentieth Century. Cambridge, MA: Harvard University Press.

Piven, Frances Fox, and Richard Cloward. 1993. Regulating the Poor: The Functions of Public Welfare. New York: Vintage.

Popkin, Susan J. 2016. No Simple Solutions: Transforming Public Housing in Chicago. Washington, DC: Urban Institute Press.

Popkin, Susan J., Victoria E. Gwiasda, Lynn M. Olsen, Dennis P. Rosenbaum, and Larry Burton. 2000. The Hidden War: Crime and the Tragedy of Public Housing in Chicago. New Brunswick, NJ: Rutgers University Press.

Purser, Gretchen. 2014. "The Circle of Dispossession: Evicting the Urban Poor in Baltimore." Critical Sociology 1-23.

Quigley, John M., and Steven Raphael. 2004. "Is Housing Unaffordable? Why Isn't It More Affordable?" The Journal of Economic Perspectives 18(1):191-214.

Raymond, Elora, Richard Duckworth, Ben Miller, Michael Lucas, and Shiraj Pokharel. 2016. Corporate Landlords, Institutional Investors, and Displacement: Eviction Rates in Single- Family Rentals. Atlanta, GA: Federal Reserve Bank of Atlanta.

Riis, Jacob. 1890. How the Other Half Lives: Studies Among the Tenements of New York. New York: Charles Scribner's Sons.

Rosen, Eva. 2014. "Rigging the Rules of the Game: How Landlords Geographically Sort LowIncome Renters." City \& Community 13(4):310-40. 
Rosen, Eva, Philip Garboden, and Jennifer E. Cossyleon. 2019. "Discrimination without Discriminants: Racial Logics in Tenant Screening.” Working Paper.

Sampson, Robert J. 2012. Great American City: Chicago and the Enduring Neighborhood Effect. Chicago: Chicago University Press.

Satter, Beryl. 2009. Family Properties: Race, Real Estate, and the Exploitation of Black Urban America. Macmillan.

Schram, Sanford F. 2006. Welfare Discipline: Discourse, Governance and Globalization. Philadelphia: Temple University Press.

Schram, Sanford F., Richard C. Fording, and Joe Soss. 2008. "Neo-Liberal Poverty Governance: Race, Place and the Punitive Turn in US Welfare Policy." Cambridge Journal of Regions, Economy and Society 1(1):17-36.

Schram, Sanford F., Joe Soss, Richard C. Fording, and Linda Houser. 2009. "Deciding to Discipline: Race, Choice, and Punishment at the Frontlines of Welfare Reform." American Sociological Review 74(3):398-422.

Schwartz, Alex F. 2015. Housing Policy in the United States. 3rd ed. New York: Routledge.

Shroder, Mark. 2001. "Moving to Opportunity: An Experiment in Social and Geographic Mobility." Cityscape: A Journal of Policy Development and Research 5(2):57-67.

Simon, Jonathan. 1997. Poor Discipline: Parole and the Social Control of the Underclass. Chicago: University Of Chicago Press.

Smith, Neil. 1996. The New Urban Frontier: Gentrification and the Revanchist City. New York: Routledge.

Solari, Claudia D., and Robert D. Mare. 2012. "Housing Crowding Effects on Children's Wellbeing." Social Science Research 41(2):464-76.

Soss, Joe, Richard C. Fording, and Sanford F. Schram. 2011. Disciplining the Poor: Neoliberal Paternalism and the Persistent Power of Race. University of Chicago Press.

Spence, Lester K. 2015. Knocking the Hustle: Against the Neoliberal Turn in Black Politics. Punctum Books.

Steensland, Brian. 2006. "Cultural Categories and the American Welfare State: The Case of Guaranteed Income Policy.” American Journal of Sociology 111(5):1273-1326.

Stegman, Michael A. 1972. Housing Investment in the Inner City. Cambridge: The MIT Press.

Sternlieb, George. 1966. The Tenement Landlord. First Edition. New Brunswick: Rutgers University Press. 
Sternlieb, George. 1972. The Urban Housing Dilemma: The Dynamics of New York City's Rent Controlled Housing. New York: Housing and Development Administration.

Stuart, Forrest. 2016. Down, Out, and Under Arrest: Policing and Everyday Life in Skid Row. Chicago: Chicago University Press.

Tach, Laura M. 2009. "More than Bricks and Mortar: Neighborhood Frames, Social Processes, and the Mixed-Income Redevelopment of a Public Housing Project." City \& Community 8(3):269-99.

Turner, Margery Austin, Stephen L. Ross, George C. Galster, and John Yinger. 2002. Discrimination in Metropolitan Housing Markets. Washington, DC: U.S. Department of Housing and Urban Development.

Vale, Lawrence J. 2000. From the Puritans to the Projects Public Housing and Public Neighbors. Cambridge, MA: Harvard University Press.

Wacquant, Loïc. 2009. Punishing the Poor: The Neoliberal Government of Social Insecurity. First edition, paperback issue edition. Durham NC: Duke University Press Books.

Watkins-Hayes, Celeste. 2009. The New Welfare Bureaucrats: Entanglements of Race, Class, and Policy Reform. Chicago: Chicago University Press.

Western, Bruce. 2007. Punishment and Inequality in America. New York: Russell Sage Foundation.

Western, Bruce, Deirdre Bloome, Benjamin Sosnaud, and Laura Tach. 2012. "Economic Insecurity and Social Stratification.” Annual Review of Sociology 38(1):341-59.

Wilson, William Julius. 1987. The Truly Disadvantaged: The Inner City, the Underclass, and Public Policy. Chicago: University Of Chicago Press.

Yinger, John. 1997. Closed Doors, Opportunities Lost: The Continuing Costs of Housing Discrimination. Russell Sage Foundation. 


\begin{tabular}{|c|c|c|c|c|c|}
\hline Demographics & & all & Baltimore & Cleveland & Dallas \\
\hline Total Sample & $\mathrm{n}$ & 127 & 36 & 56 & 35 \\
\hline \multicolumn{6}{|l|}{ Respondent Race } \\
\hline Black & $\%$ & 40 & 42 & 47 & 27 \\
\hline White & $\%$ & 47 & 58 & 41 & 42 \\
\hline Other & $\%$ & 13 & 0 & 12 & 31 \\
\hline Respondent Male & $\%$ & 60 & 51 & 70 & 52 \\
\hline \multicolumn{6}{|c|}{ Business Size (Units Owned or Managed) } \\
\hline Small (1-5 Units) & $\%$ & 22 & 24 & 25 & 13 \\
\hline Medium (6-30 Units) & $\%$ & 40 & 36 & 43 & 39 \\
\hline Large (31-100 Units) & $\%$ & 17 & 21 & 20 & 6 \\
\hline Huge (100+ Units) & $\%$ & 22 & 18 & 13 & 42 \\
\hline \multicolumn{6}{|l|}{ Business Type } \\
\hline Landlord & $\%$ & 77 & 78 & 82 & 66 \\
\hline Property Manager & $\%$ & 30 & 28 & 23 & 47 \\
\hline Rehabber/Flipper & $\%$ & 32 & 28 & 33 & 34 \\
\hline
\end{tabular}

Source: Tabulation of respondent

demographics.

Note: Business types are not mutually

exclusive.

\section{Notes:}

\footnotetext{
${ }^{i}$ While many of these screening tools are racially coded, very few properties attract a racially heterogeneous set of applicants. The majority of landlord choices are intra-racial rather than inter-racial.
} 